(c) $(1) \Theta$

Creative Commons Attribution -

NonCommercial 4.0 International License
Stručni rad

https://doi.org/10.31784/zvr.7.1.20

Datum primitka rada: 18. 1. 2019.

Datum prihvaćanja rada: 14. 2. 2019.

\title{
PROBLEM PARKIRANJA U CENTRU GRADA KRKA S PRIJEDLOZIMA VARIJANTNIH RJEŠENJA
}

\author{
Damir Pilepić \\ Struč. spec. ing. traff., predavač, Veleučilište u Rijeci, Vukovarska 58, 51000 Rijeka, Hrvatska; \\ e-mail:damir.pilepic@veleri.hr \\ Josip Sigurnjak \\ Bacc. ing. traff., student, Veleučilište u Rijeci, Vukovarska 58, 51000 Rijeka, Hrvatska; \\ e-mail:jsigurnj@veleri.hr \\ Arianna Čučuković \\ Bacc. ing. traff., studentica, Veleučilište u Rijeci, Vukovarska 58, 51000 Rijeka, Hrvatska; \\ e-mail:acucukov@veleri.hr
}

\section{SAŽETAK}

U radu je prikazana problematika parkiranja u Gradu Krku. Povećanje broja vozila na cestama ima za posljedicu smještaj odnosno parkiranje vozila. Taj problem najviše se odražava u velikim gradovima i gradovima smještenim na obali u kojima se za vrijeme ljetnih mjeseci povećava populacija u vidu turista koji dolaze u velikom broju. Grad Krk predstavlja jedno od najznačajnijih turističkih odredišta istoimenog otoka i kao takvo privlači sve veći broj turista na svojem području. Porast broja vozila koja ulaze u sam centar grada u potrazi za parkirnim mjestom, pogotovo u ljetnim mjesecima, rezultira prometnim zagušenjem, što ima za posljedicu onečišćenje zraka vozilima koja proizvode ispušne plinove, a porast buke negativno utječe i na lokalno stanovništvo. Za rješavanje problematike parkiranja u Gradu Krku predlažu se tri varijante kojima se povećavaju parkirališni kapaciteti za parkiranje vozila u centru grada. U navedenim varijantama garažno-parkirni objekt predstavlja glavni predmet rješavanja problema parkiranja, gdje se uz izgradnju navedenog objekta i uklanjanjem postojećih parkirnih mjesta povećavaju parkirališni kapaciteti. Cilj rada je da se kroz predložene varijante rješenja prikažu pozitivni učinci rješavanja problema parkiranja u Gradu Krku koje se očituje u rasterećenju prometnica u samom centru grada od vozila koja su u potrazi za parkirnim mjestima. Posljedica je smanjenje prometnih zagušenja, a time se smanjuje i onečišćenje zraka i utjecaj buke na lokalni okoliš, što ima pozitivne učinke na kvalitetu života za lokalno stanouništvo. Surha rada je prikazati problematiku parkiranja jednog grada i način na koji se navedeni problem može riješiti, uzevši u obzir raspoloživi prostor i pravila odvijanja prometnih tokova na području grada.

Ključne riječi: Grad Krk, parkiranje, parkirna mjesta, garažno-parkirni objekt 


\section{UVOD}

Gradovi smješteni na obali Jadranskog mora privlače velik broj turista tijekom ljetnih mjeseci. Povećanjem broja turista, uzimajući u obzir i broj lokalnog stanovništva, gradovi postaju prenapučeni, što se negativno odražava na promet, pogotovo cestovni. U pogledu cestovnog prometa tu se prije svega misli na ponudu parkirnih mjesta koja nude pojedini gradovi smješteni na obali mora. Turisti na najrazličitije načine mogu doći do svoje destinacije, bilo autobusom, taksijem ili unajmljivanjem automobila. Posljednje navedeno, unajmljivanje automobila ili, popularno, rent a car, nalazi svoju korist u velikom broju korisnika koji na određenu destinaciju dolaze zrakoplovom te nakon toga nastavljaju svoje putovanje automobilom. Stoga gradovi na obali moraju imati adekvatnu ponudu parkirnih mjesta za smještaj sve većeg broja automobila koji dolaze u vrijeme turističke sezone, a koja bi trebala biti nerijetko višestruko veća od izvansezonske potražnje.

Grad Krk središte je istoimenog otoka te poznato turističko središte koje tijekom ljetnih mjeseci doživljava velik porast broja vozila koja ulaze u sam centar grada u potrazi za parkirnim mjestima, pa zbog nedostatka parkirnih mjesta stvaraju prometna zagušenja u samom centru grada. Navedeno se negativno održava na okoliš, ali i na lokalno stanovništvo, ne samo zbog ispušnih plinova već i zbog zagađenja bukom koju proizvode vozila.

Cilj rada je da se kroz utvrđivanje broja postojećih parkirnih mjesta kojima Grad Krk raspolaže i mogućnošću izgradnje garaže prikaže nekoliko varijanti s kojima bi Grad Krk ublažio problem parkiranja u svom središtu.

\section{OPĆE ZNAČAJKE GRADA KRKA}

Grad Krk nalazi se na istoimenom otoku smještenom na sjevernom Jadranu, u središtu Kvarnerskog zaljeva. Na otoku Krku nalazi se i Zračna luka Rijeka koja je udaljena svega 30 km, a koja unatrag pet godina bilježi stalni porast broja putnika (2018. godine broj putnika iznosio je 183.606, kao što je to vidljivo u tablici 1).

Tablica 1. Promet putnika u Zračnoj luci Rijeka u razdoblju od 2014. do 2018. godine

\begin{tabular}{|c|c|}
\hline GODINA & UKUPNO \\
\hline 2014. & 106.235 \\
\hline 2015. & 139.718 \\
\hline 2016. & 145.297 \\
\hline 2017. & 142.111 \\
\hline 2018. & 183.606 \\
\hline
\end{tabular}

Izvor: http://rijeka-airport.hr/pages/sub/25/doc_hr/mjesecni-tijek-putnika-i-operacija-zrakoplova-2011-2019---sijecanj. pdf, 8. 2. 2019.

Grad Krk sastoji se od 15 naselja te prema posljednjem popisu stanovništva iz 2011. g. u njemu živi 6.281 stanovnik u 2.380 kućanstava, odnosno 2.355 stanova (https://www.dzs.hr/, 8. 2. 2019.). 
Područje Grada Krka obuhvaća prostor od 110,41 km² na kopnu, što iznosi oko 3,07 \% ukupne površine teritorija Primorsko-goranske županije i površinu od $152,27 \mathrm{~km}^{2}$ morskog dijela. Duljina obalne linije Grada Krka je 62,50 kilometara. S kopnom je povezan 1430 m dugačkim Krčkim mostom izgrađenim 1980. godine. (Host et al., 2016:18)

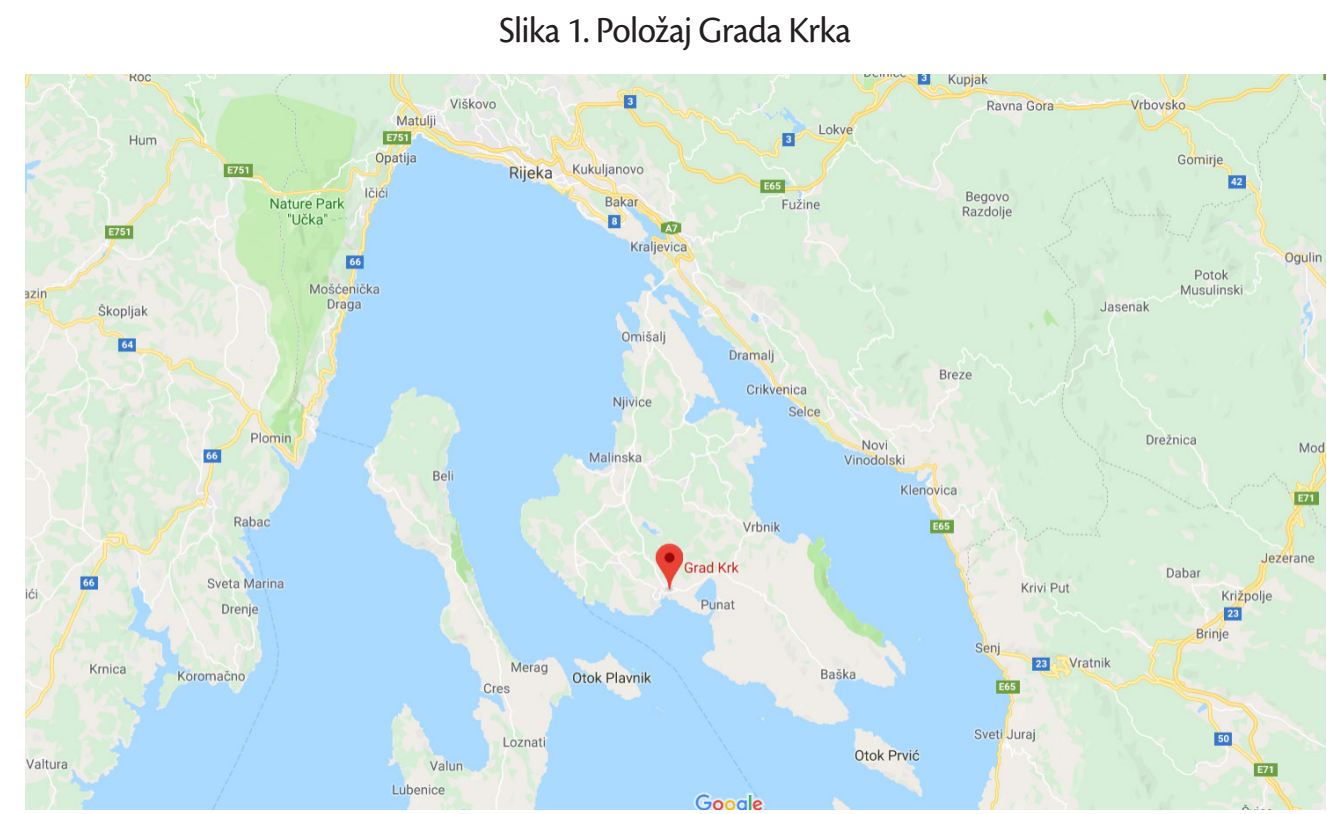

Izvor: obrada autora

\section{ANALIZA POSTOJEĆEG STANJA}

U nastavku se opisuje cestovni promet što uključuje ceste koje se nalaze na području Grada Krka. Također, opisuju se parkirališni prostori te turistički promet koji je od velike važnosti i temelj nužnosti povećanja broja parkirnih mjesta u samome gradu.

\section{1 Cestovni promet}

Do Grada Krka dolazi se državnom cestom D102 koja prolazi cijelim otokom Krkom i županijskom cestom Ž5131 i Ž5106 koja služi kao pristupna cesta samom središtu grada. 
Slika 2. Glavni cestovni pravci povezanosti Grada Krka

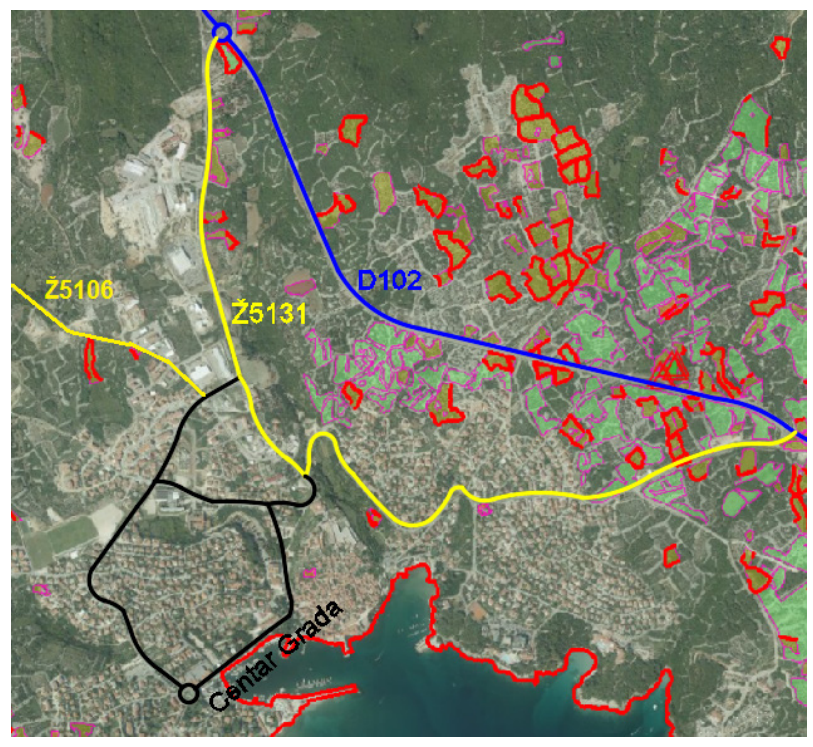

Izvor: obrada autora prema http://www.arkod.hr/, 11. 11. 2018.

Prema Odluci o razvrstavanju javnih cesta (NN 66/15) na području Grada Krka nalaze se sljedeće javne ceste:

- dio D102 (Šmrika - Krk - Baška) u duljini od 11,2 km

- dio D104 (D102 - trajektna luka Valbiska) 10,1 km

- $\quad \check{Z} 5106($ Vrh - Krk) 4,2 km

- dio Ž5107 (Kras - D102) 5,3 km

- $\quad \check{Z} 5131$ (D102 - Krk - D102) 3,5 km

- $\quad$ L58085 (Brzac - Milohnići - Poljica - Bajčići - L58090) 8,8km

- $\quad$ L58086 (L58085 - Linardići - Vrh) 8,3 km

- $\quad$ L58087 (D104 - Skrbčići - L58086) 1,3 km

- $\quad$ L58088 (Pinezići - D104) 0,7 km

- $\quad \mathrm{L} 58090($ Vrh - D102) $3,5 \mathrm{~km}$

- $\quad$ L58091 (Kornić - D102) 1,2 km.

Na području Grada se, prema Registru nerazvrstanih cesta, nalazi 137,36 km nerazvrstanih cesta, dakle, ceste koje se koriste za promet vozilima i koje svatko može slobodno koristiti, a koje nisu razvrstane kao javne ceste. Registar nije zadovoljavajući (nedostaju detaljni podaci o širinama, 
opremljenosti, potrebama rekonstrukcije i sl.). Nerazvrstane ceste na području Grada obuhvaćaju ulice (ceste u naselju), seoske ceste i putove (ceste u selu i među zaselcima), poljske putove (pristup poljoprivrednom i šumskom zemljištu) i ceste koje spajaju dva naselja (Blečić et al., 2015:26).

Mreža nerazvrstanih cesta je, osim unutar samog Krka, mahom substandardna: profili su uski i bez nogostupa, s neadekvatnim trasiranjem (oštri zavoji, slabo pregledna križanja, vijugavost). No, s obzirom na malu veličinu naselja, posljedična sporost vožnje i mala protočnost prometnica, osim neudobnosti, ne predstavljaju primjetan problem za odvijanje života u naseljima. Spomenuti nedostaci izraženiji su u mjestima značajnijeg sezonskog karaktera (osobito Kornić i Pinezići), gdje su neplanski građene prometnice izložene velikom prometnom opterećenju u ljetno doba, pa mogu predstavljati ograničavajući faktor za daljnje širenje naselja te podizanje kvalitete života i unapređenje turističke ponude. Navedeni problemi javljaju se i u nekim od rubnih dijelova mjesta Krk, ali u manje izraženoj mjeri. (Blečić et al., 2015:26)

Tablica 2. Broj vozila na ulazu u Grad Krk s D102 na Ž5131

\begin{tabular}{|c|c|c|}
\hline \multirow{2}{*}{ GODINA } & \multicolumn{2}{|c|}{ Ž5131 } \\
\cline { 2 - 3 } & PGDP & PLDP \\
\hline 2013. & 4.329 & 9.271 \\
\hline 2014. & 4.382 & 9.388 \\
\hline 2015. & 4.549 & 9.664 \\
\hline 2016. & 4.847 & 10.137 \\
\hline 2017. & 5.178 & 10.773 \\
\hline
\end{tabular}

Izvor: Brojenje prometa na cestama Republike Hrvatske 2013., 2014., 2015., 2016., 2017.

Prema prethodnoj tablici može se vidjeti prosječni godišnji dnevni promet (PGDP) i prosječni ljetni dnevni promet (PLDP) vozila koja ulaze u Grad Krk s DC102 na ŽC5131 u razdoblju od 2013. do 2017. godine. Prosječni ljetni dnevni promet u navedenom se razdoblju povećao za oko 1500 vozila, dok u istom razdoblju prosječni godišnji promet u istom razdoblju bilježi povećanje za oko 800 vozila.

Na temelju navedene tablice može se zaključiti da Grad Krk bilježi konstantan porast broja vozila koja ulaze u grad, međutim, kako na temelju brojenja nije jasno o kojim je vozilima riječ, te se njihov broj povećava iz godine u godinu, nije moguće napraviti analizu potražnje za parkiranjem na području obuhvata.

\section{2 Parkirališni prostori}

Brz porast stupnja motorizacije doveo je do problema u normalnom odvijanju prometa općenito. Taj problem naročito je istaknut kod stacionarnog prometa, a posebice u strogom centru gradova, budući da su tamo u pravilu koncentrirani najatraktivniji sadržaji koji privlače dodatni promet. 
D. Pilepić, J. Sigurnjak, A. Čučuković: Problem parkiranja u centru Grada Krka s prijedlozima... Zbornik Veleučilišta u Rijeci, Vol. 7 (2019), No. 1, pp. 359-373

S obzirom na to da je u središtima gradova, posebice u starim dijelovima gradova, mali omjer između prometnih površina i površina zauzetih zgradama, uz već spomenutu atraktivnost gradskog središta, najveći problemi dinamičkog i stacionarnog prometa bit će u tim zonama grada.

Ponuda parkirnih mjesta na javnim parkiralištima Grada Krka definirana je Odlukom o uređenju prometa u Gradu Krku, te su kao javna parkirališta određena sljedeća:

- Parkiralište Centar (52 PM + 5 PM za invalide);

- Parkiralište Robna kuća (114 PM + 5 PM za invalide);

- Parkiralište Kružni tok (158 PM + 6 PM za invalide); $i$

- Parkiralište Portapižana (61 PM + 3 PM za invalide + 8 PM za motocikle).

- Ukupno 412 PM.

Slika 3. Prikaz parkirnih mjesta u centru Grada Krka

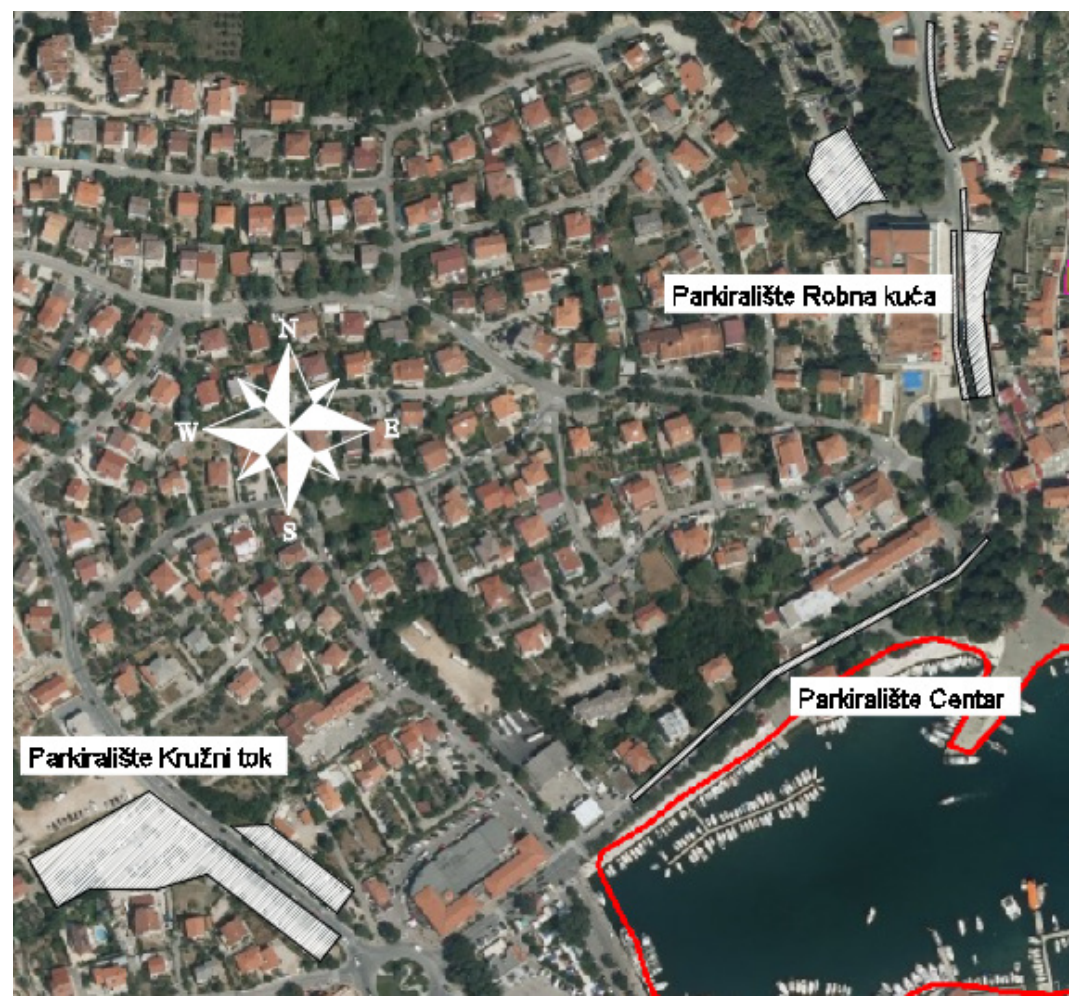

Izvor: obrada autora prema https://geoportal.dgu.hr/, 27. 11. 2018.

Provođenje naplate parkiranja vrši se na temelju Odluke o organizaciji i načinu naplate parkiranja. Ovom Odlukom određene su parkirališne površine, organizacija, način korištenja i način naplate, te nadzor nad parkiranjem vozila na javnim parkiralištima s naplatom na području Grada Krka. 
Na stalnim javnim parkiralištima parkiranje se naplaćuje od 1. lipnja do 30. rujna, u vremenu od 8.00 do 22.00 sata. Za korištenje javnih parkirališta korisnik mora imati parkirališnu kartu koja se izdaje kao dnevna ili satna. Dnevna vrijedi od trenutka izdavanja do istog vremena u prvom sljedećem danu, dok se za kraće vrijeme korištenja parkirališta dnevna karta izdaje kao jednosatna ili višesatna. Ako korisnik parkirališta ne kupi parkirališnu kartu smatra se da je preuzeo dnevnu koju je dužan platiti u roku od osam dana. Osim toga, korisnik parkirališta mora u roku od 15 minuta od parkiranja vozila valjanu parkirališnu kartu vidljivo istaknuti s unutarnje strane vjetrobranskog stakla ili se smatra da je pristao preuzeti dnevnu kartu. (Odluka o uređenju prometa).

Cijena parkirališne karte po satu na svim stalnim javnim parkiralištima s naplatom u gradu Krku iznosi 7,00 kn, dok je dnevna procijenjena na 98,00 kn.

Naplata parkiranja provodi gradska komunalna tvrtka VECLA d. o. o. Krk na temelju ugovora o povjeravanju poslova organizacije i naplate parkiranja na privremenim parkirnim površinama $u$ gradu Krku.

\section{3 Turistički promet}

Budući da je grad Krk prije svega turistički grad, u kojem se tijekom ljetnih mjeseci povećava broj ljudi koji obitavaju u gradu, u ovom poglavlju prikazat će se kretanje prometa turista od 2015. do 2018. godine. U promatranom razdoblju prikazat će se dolasci i noćenja turista u Gradu Krku.

Tablica 3. Dolasci i noćenja turista u Gradu Krku

\begin{tabular}{|l|l|l|}
\hline & Dolasci & Noćenja \\
\hline 2015. & 180.203 & 1.055 .540 \\
\hline 2016. & 196.290 & 1.135 .190 \\
\hline 2017. & 215.958 & 1.264 .827 \\
\hline 2018. & 229.938 & 1.317 .312 \\
\hline
\end{tabular}

Izvor: http://www.krk.hr/Iz_Rada_Turisticke_Zajednice/Statistika, 8. 2. 2019.

Kako se može vidjeti na prethodnoj tablici, broj dolazaka turista u Grad Krk je od 2015. godine u stalnom porastu, povećan u razdoblju od tri godine za 50000 dolazaka. Broj noćenja gostiju u istom razdoblju također je imao porast za skoro 300000 noćenja.

\section{PRIJEDLOZI VARIJANATA ZA RJEŠAVANJE PROBLEMA PARKIRANJA U GRADU KRKU}

U nastavku se prikazuju tri varijante koje povećavaju broj parkirnih mjesta u samom centru grada, te na taj način utječe na smanjenje gužve, ispušnih plinova i buke, odnosno pozitivno utječe na cjelokupni promet u samom centru grada. 


\section{1 Varijanta 1}

U Varijanti 1 predlaže se izgradnja garažno-parkirnog objekta (u daljnjem tekstu GPO) u jednom dijelu postojećeg parkirališta „Robna kuća“, koji bi se sastojao od prizemlja, prve i druge etaže. Prizemlje i prva etaža bili bi rezervirani za 106 parkirnih mjesta (PM), dok bi druga etaža obuhvaćala oko $1000 \mathrm{~m}^{2}$ poslovnog prostora, a ostala površina iskoristila bi se za uređenje zone parka i pješački prolaz od centra do gradskog groblja.

Predmetni objekt (garažno-parkirni objekt, poslovni prostor i park) smjestio bi se na postojećim česticama k. č. br. 3194/3, 3194/4, 3195/1, 3195/2, 3195/3, 3196//3, a njen točan oblik i veličina vidljiv je na sljedećoj slici.

Slika 4. Prikaz katastarskih čestica uključenih u zahvat

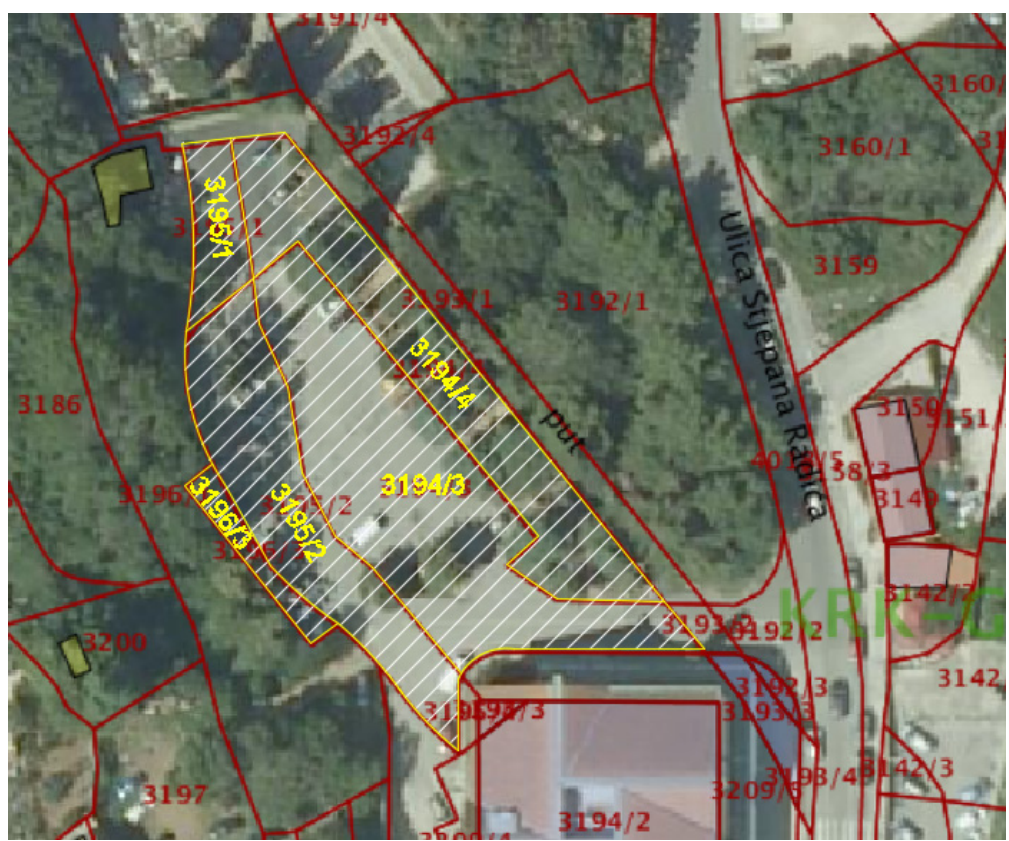

Izvor: obrada autora prema https://oss.uredjenazemlja.hr/public/cadServices.jsp?action=dkpViewerPublic, 29. 9. 2018.

Uklanjanjem postojećih 56 parkirnih mjesta na postojećem parkiralištu kod Robne kuće i izgradnjom garažno-parkirnog objekta koji bi obuhvaćao 106 parkirnih mjesta dobilo bi se 50 parkirnih mjesta više u odnosu na postojeće stanje parkirališta. 
Slika 5. Prikaz lokacije postavljanja GPO-a

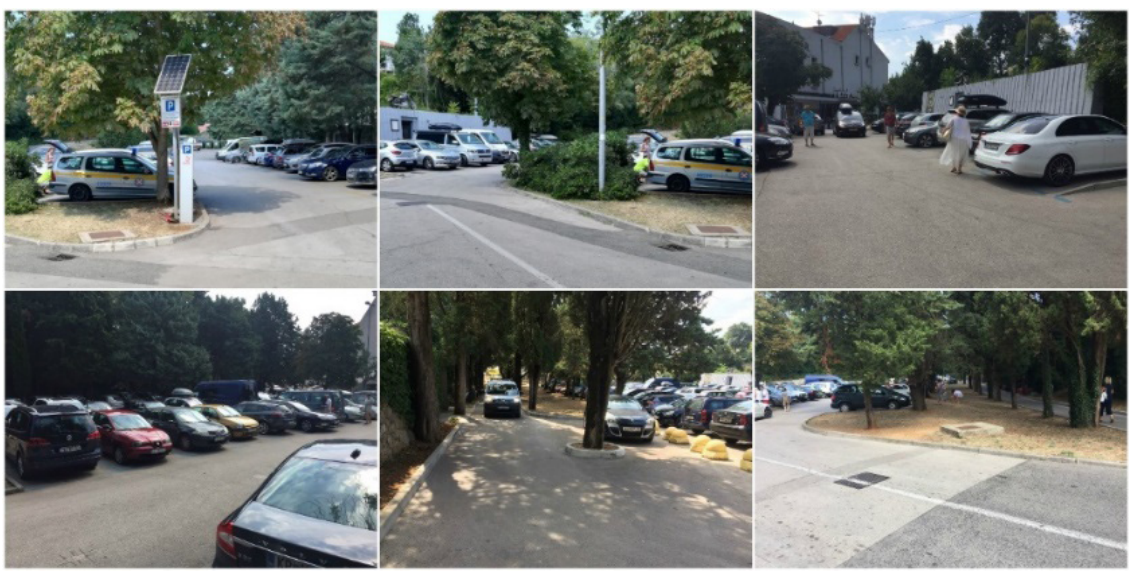

Izvor: obrada autora, 2. 8. 2018.

Predložena tlocrtna površina GPO-a je $1600 \mathrm{~m}^{2}$. Dužina GPO-a u najdužem dijelu iznosi 75 m, a u najširem dijelu iznosi oko $36 \mathrm{~m}$. Visina garaže iznosi 2,50 m. Korisnicima garaže ulazak će biti omogućen iz Ulice Stjepana Radića preko rampe koja će ih voditi na prvu etažu, gdje će se u potrazi za parkirnim mjestom moći spustiti u prizemlje, gdje će se nalaziti i izlazna rampa. Izlaz iz garaže trebao bi biti organiziran tako da se vozila kroz pristupnu cestu priključuju na Ulicu Stjepana Radića te se na taj način udaljavaju od centra grada.

Slika 6. Prikaz prizemlja i prve etaže predlaganog GPO-a

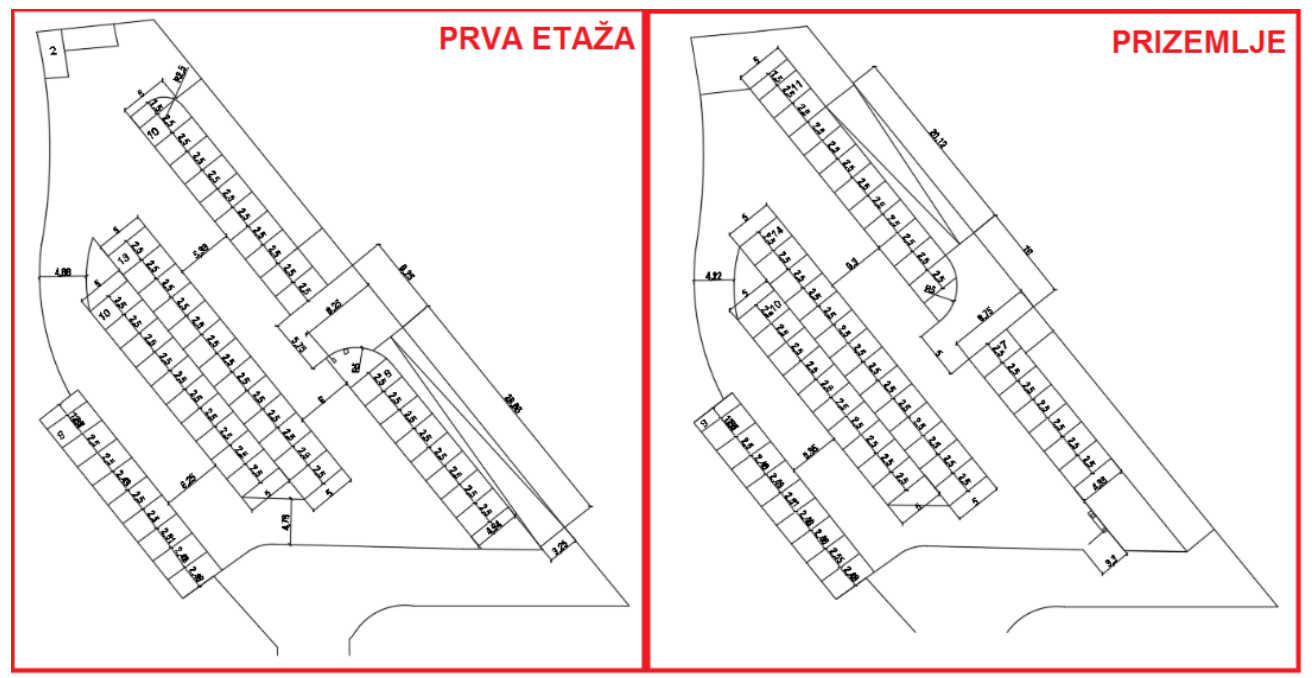

Izvor: obrada autora 


\section{Pilepić, J. Sigurnjak, A. Čučuković: Problem parkiranja u centru Grada Krka s prijedlozima...}

Zbornik Veleučilišta u Rijeci, Vol. 7 (2019), No. 1, pp. 359-373

Danas se do područja na kojem će se smjestiti GPO dolazi jednosmjernom cestom koja prolazi kroz centar grada. Kako bi se izbjeglo u ljetnim mjesecima da vozila koja namjeravaju parkirati u GPO-u prolaze kroz centar grada, gdje bi se dodatno stvorile gužve, potrebno je učiniti rekonstrukciju, tako da se cesta koja vodi prema izlazu s područja centra grada pretvori u dvosmjernu cestu, što bi imalo učinak rasterećenja samog centra grada od vozila koja ulaze u garažu.

Slika 7. Situacija prostora sa stajališta prometa

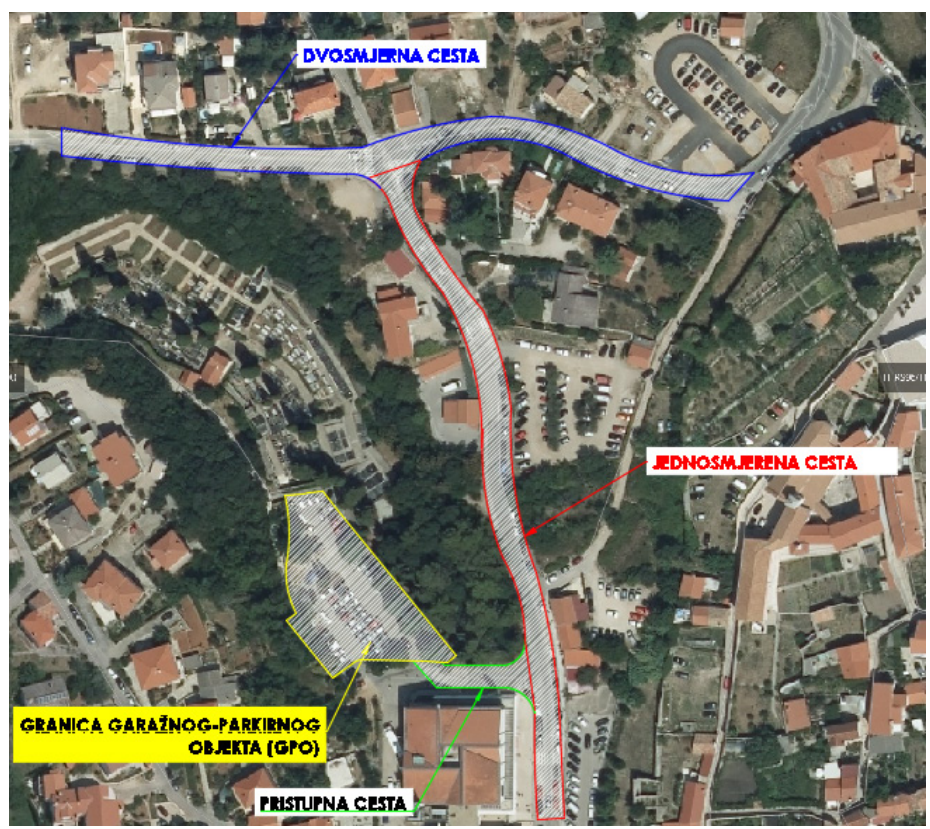

Izvor: obrada autora prema www.geoportal.dgu.hr, 12. 11. 2018.

Postojeća jednosmjerna Ulica Stjepana Radića ima sve uvjete da se rekonstruira u dvosmjernu ulicu; na slici 8 prikazuje se moguće prometno rješenje. 
Slika 8. Prikaz rješenja prometne signalizacije za potrebe GPO-a

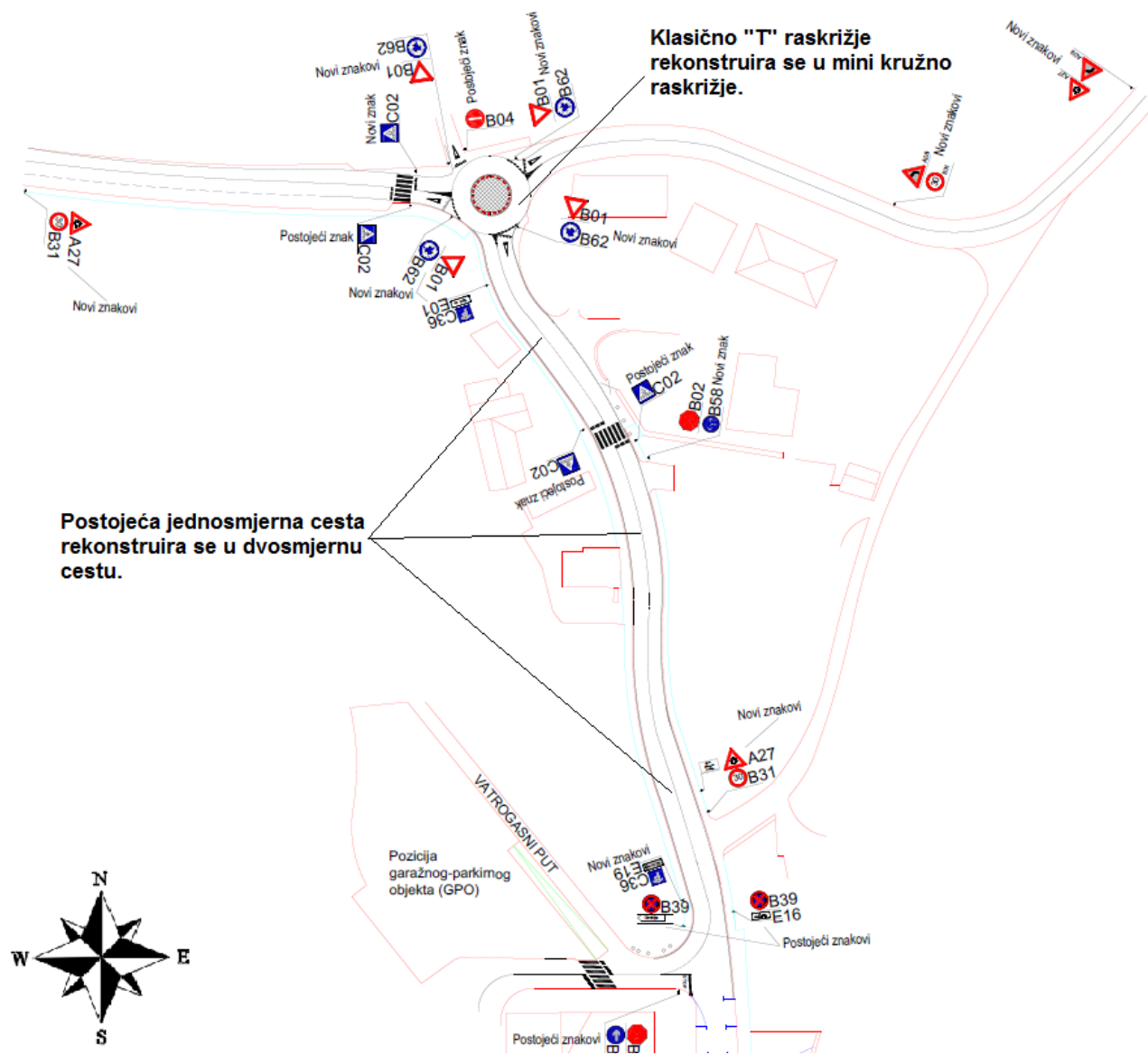

Izvor: obrada autora

Implementacijom varijante 1 odnosno izgradnjom garažno-parkirnog objekta na postojećem parkirališnom prostoru „Robna kuća“ postojeći kapacitet parkiranja povećao bi se za 50 parkirnih mjesta.

\section{2 Varijanta 2}

U drugoj varijanti, uz izgradnju GPO-a koji bi povećao broj parkirnih mjesta za 102 PM + 4 za osobe s invaliditetom, uklonilo bi se postojeće 71 parkirno mjesto na potezu od benzinske pumpe INA do raskrižja Ulice Stjepana Radića, Vinogradarske i ulice Borik, izuzev 16 parkirnih mjesta za motocikle, dvaju parkirnih mjesta za električne automobile i 12 parkirnih mjesta za potrebe dostave.

Uklanjanjem navedenih parkirnih mjesta postiglo bi se smanjenje zagađenja i smanjenje prometnih zagušenja u samom centru grada. 
Implementacijom varijante 2 postojeći kapacitet parkiranja povećao bi se za 35 parkirna mjesta te bi se olakšala komunikacija u samom centru grada. Navedenim ostvarenjem povećava se površina koju su zauzeli automobili u samom centru grada, što otvara mogućnost za implementaciju biciklističke staze kroz sam centar grada.

Slika 9. Prikaz parkirnih mjesta koja se uklanjaju u drugoj varijanti

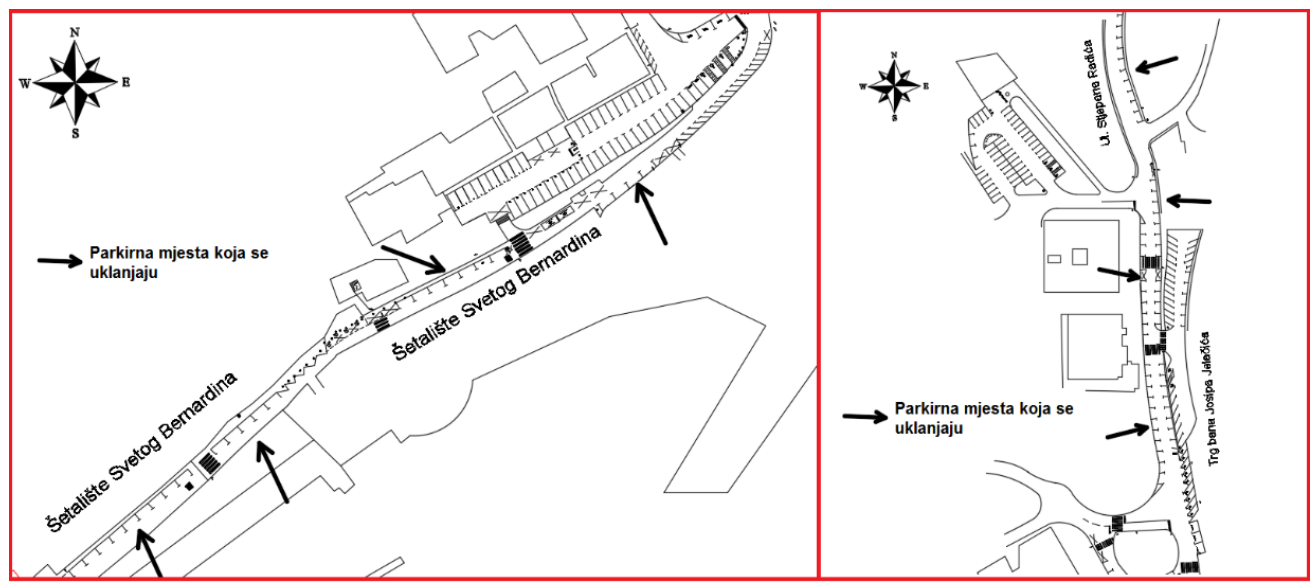

Izvor: obrada autora

\section{3 Varijanta 3}

U trećoj varijanti bi se, uz izgradnju GPO-a koji bi povećao broj parkirnih mjesta za 102 PM + 4 za osobe $s$ invaliditetom, uklonilo 98 parkirnih mjesta na potezu od benzinske pumpe INA do raskrižja Ulice Stjepana Radića, Vinogradarske i ulice Borik i parkiralište koje je pod naplatom, a nalazi se preko puta Robne kuće i broji 27 parkirnih mjesta. Tada bi u samom središtu grada uz Ulicu Stjepana Radića ostalo 16 parkirnih mjesta za motocikle, dva parkirna mjesta za električne automobile i 12 parkirnih mjesta za potrebe dostave, a sva ta parkirna mjesta imaju mogućnost povećanja broja ovisno o budućim potrebama.

Uklanjanjem navedenih parkirnih mjesta postiže se smanjenje zagađenja od ispušnih plinova u centru grada, kao i smanjenje prometne gužve na navedenom potezu. $S$ druge strane, Gradu Krku bi na prostoru sadašnjeg parkirališta koje se nalazi preko puta Robne kuće ponudio dodatni prostor na kojem bi se mogla proširiti turistička ponuda, što bi dovelo do višestruke koristi i za grad i za njegove građane.

Uklanjanjem navedenih parkirnih mjesta oslobodilo bi se oko $1400 \mathrm{~m}^{2}$ korisnog prostora koji se može prenamijeniti u neku drugu svrhu.

Implementacijom varijante 3 postojeći kapacitet parkiranja povećao bi se za 8 parkirnih mjesta, što predstavlja neznatno povećanje parkirnih mjesta, te je u odnosu na ostale predložene varijante nepovoljno rješenje. 
Slika 10. Prikaz parkirnih mjesta koja se uklanjanju u trećoj varijanti

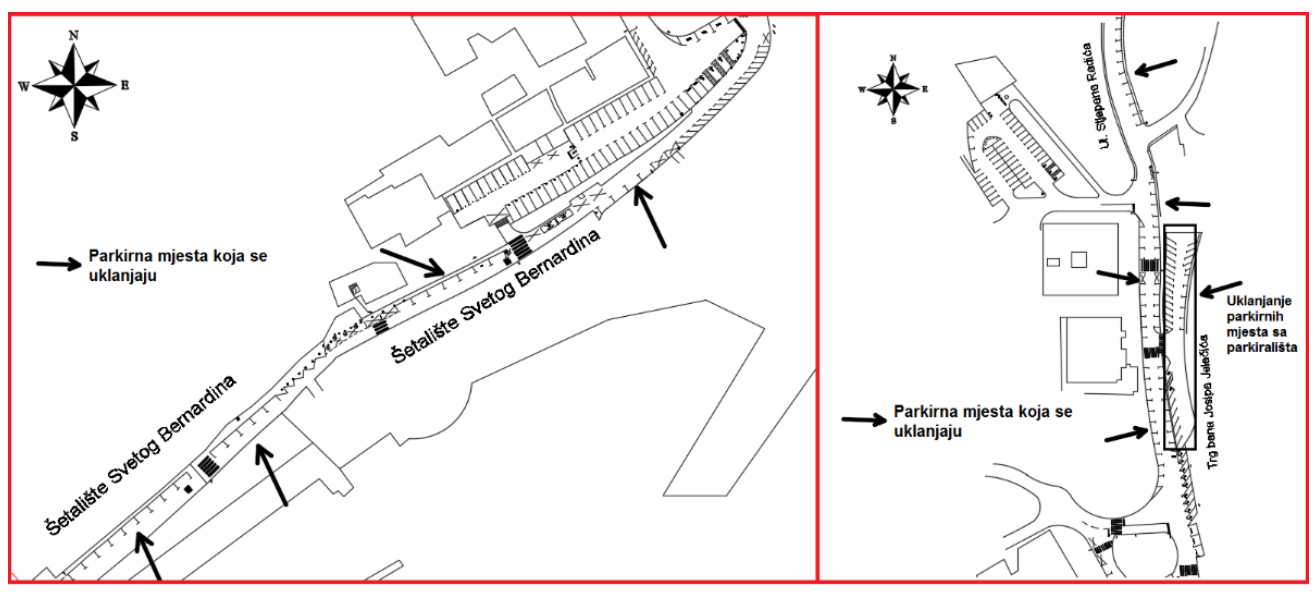

Izvor: obrada autora

\section{ZAKLJUČAK}

Grad Krk, smješten na istoimenom otoku, predstavlja turističko središte koje privlači sve veći broj turista iz godine u godinu, a koje se posebice odražava u ljetnim mjesecima. Povećava se broj populacije u ljetnim mjesecima, a dio turista koji dolaze na otok Krk zrakoplovom koristi usluge rent a cara za dolazak u centar Grada Krka te time, u nemogućnosti pronalaska parkirnog mjesta, uzrokuju prometna zagušenja. Za prijedlog rješenja koji će zadovoljiti zahtjeve potrebe za parkirnim mjestima predložene su tri varijantne. Optimalna varijanta, odnosno ona koja nudi povećanje parkirnih mjesta, je varijanta jedan koja predstavlja izgradnju garažno-parkirnog objekta, čime bi se ponuda povećala za 50 parkirnih mjesta. Druga varijanta povećava kapacitet za 35 parkirnih mjesta te osim izgradnje garažnog-parkirnog objekta predlaže uklanjanje postojećih parkirnih mjesta, smještenih u samom centru grada. Navedenom implementacijom pojavljuje se mogućnost postavljanja biciklističke staze koja bi prolazila središtem grada. Treća varijanta daje najmanji broj parkirnih mjesta od predloženih varijanti te se veže uz drugu varijantu po pitanju izgradnje biciklističke staze. Navedene varijantne omogućile bi s jedne strane povećanje ponude parkirnih mjesta, a s druge strane bi Grad Krk dobio slobodan prostor koji može iskoristiti za uređenje prostora u neku drugu svrhu (postavljanje biciklističke staze ili pješačke staze). Centar grada bio bi oslobođen vozila koja stvaraju prometna zagušenja i stvaraju ispušne plinove jer bi im pristup za parkiranje u garažnom-parkirnom objektu bio omogućen cestom koja je danas jednosmjerna. Njenom rekonstrukcijom u dvosmjernu cestu izbjegava se prolazak vozila kroz sam centar grada do garažno-parkirnog objekta. Dakle, prijedlogom triju varijantnih rješenja ostvaruje se povećanje broja parkirnih mjesta, iskorištavanje dosadašnjih parkirnih mjesta u površinu za neku drugu svrhu, i, što je najvažnije, rasterećuju se prometnice u samome centru grada, što utječe na smanjenje gužvi, smanjenje ispušnih plinova, buke i pridonosi očuvanju prirode odnosno održivom razvoju. 
D. Pilepić, J. Sigurnjak, A. Čučuković: Problem parkiranja u centru Grada Krka s prijedlozima... Zbornik Veleučilišta u Rijeci, Vol. 7 (2019), No. 1, pp. 359-373

\section{LITERATURA}

Host, A. et al., Strategija razvoja turizma Grada Krka do 2020. godine, Rijeka/Krk, svibanj 2016.

Blečić, A. et al., Izvješće o stanju u prostoru Grada Krka 2007. - 2015. - Nacrt izvješća, Rijeka, prosinac 2015.

https://www.dzs.hr/, (8. 2. 2019.)

Odluka o razvrstavanju javnih cesta (NN 66/15) na području grada Krka

Odluka o uređenju prometa grada Krka 


\title{
PARKING PROBLEM IN THE CENTRE OF THE CITY OF KRK WITH SUGGESTIONS OF VARIANT SOLUTIONS
}

\author{
Damir Pilepić \\ Spec. ing. traff., Lecturer, Polytechnic of Rijeka, Vukovarska 58, 51000 Rijeka, Croatia; \\ e-mail:damir.pilepic@veleri.hr \\ Josip Sigurnjak \\ Bacc. ing. traff., Student, Polytechnic of Rijeka, Vukovarska 58, 51000 Rijeka, Croatia; \\ e-mail: jsigurnj@veleri.hr

\section{Arianna Čučuković} \\ Bacc. ing. traff., Student, Polytechnic of Rijeka, Vukovarska 58, 51000 Rijeka, Croatia; \\ e-mail: acucukov@veleri.hr
}

\begin{abstract}
This paper presents parking issues in the City of Krk. Increasing the number of vehicles on the roads results in vehicle accommodation or parking. This problem is most evident in big towns and cities on the coast, where during the summer months the population increases because of tourists who come in large numbers. The City of Krk is one of the most important tourist destinations of the homonymous island and as such, it attracts more and more tourists in the area. The increasing number of vehicles enter the centre of the city in search of a parking space, especially in summer months, causing traffic congestion which results in air pollution from vehicles producing exhaust gases and in increased noise, all of which negatively affects the local population. In this paper three variants are proposed in order to address the parking problem in the City of Krk, by increasing the parking capacity of the vehicles in the centre of the city. In these variants, the garage-parking facility is the main object of the parking problem, where the parking facilities are expanded with the construction of the before mentioned facility and the removal of the existing parking lots. The aim of the paper is to present the proposed solutions to produce positive effects of the parking problem in the City of Krk. The solution is reflected in the relocation of roads in the very centre of the city from the vehicles that are looking for parking places which has the effect of reducing traffic congestion and thus decreasing the air pollution and having a lesser impact of noise on the local environment. It also has positive effects on the quality of life for the local population. The purpose of this paper is to show the issue of parking in a city and how this problem can be solved taking into account the available space and rules of traffic flow in the area of the city.
\end{abstract}

Key words: City of Krk, parking, parking places, garage-parking facility 